\title{
perifèria
}

Número 8, Julio 2008

www.periferia.name

\section{Anthropological Life in Bush of Ghosts. Anthropology, Anthropologist and Cultural Change in Transitional Serbia}

\author{
Bojan Žikić, Department of Ethnology and Anthropology, University of Belgrade ${ }^{1}$
}

\section{Resumen}

La celebración del Centenario del programa de Etnología y Antropología de la Universidad de Belgrado en el 2006 se constituyó como una oportunidad, no solamente para hablar sobre el glorioso pasado sino para aplicar la auto-reflexión en nuestra disciplina. La revisión de los cambios sufridos por la disciplina en una Serbia de cambiantes circunstancias sociales y culturales durante más de un siglo lleva a interrogarnos cómo las vidas de los antropólogos profesionales han sido afectadas por los acontecimientos transicionales que ha tenido lugar en los últimos veinte años, junto con un mejor conocimiento de la sociedad serbia y su cultura cuando el conocimiento es producido por personas que viven en ese particular contexto social y cultural.

Queda claro que si se quiere entender qué significa "transición" o cómo las instituciones sociales, normas o conductas se ven afectadas por un sistema social que deja de existir mientras que otro no está plenamente instalado y qué significa el cambio cultural en la vida cotidiana de la gente, se debe ser experto y testigo a mismo tiempo, confiado en su propio privilegio epistemólogico y sin embargo capaz de contribuir a los esfuerzos profesionales de una disciplina capaz de describir y entender el mundo en el que vivimos, siendo una herramienta de cultura crítica y un marco para implementar consciencia de nosotros mismos al mismo tiempo.

Por lo tanto en cierto modo el antropólogo es producido por la antropología al que pertenece su trabajo profesional, el cual está influenciado por la comunidad que da el contexto de lo que estudiado por la antropología en cierto ambiente social y cultural.

\begin{abstract}
Celebrating centennial of Ethnology and Anthropology curriculum at the University of Belgrade in 2006 happened to be not just another occasion to speak about "glorious past", or even to employ self-reflexivity to our discipline. Review of changes through which the discipline passed as the social and cultural circumstances have changed in Serbia in more than a century posed questions on how professional lives of anthropologists are affected by transitional occurrences of last twenty years or so, alongside with consequences for better understanding of Serbian society and its culture when knowledge is produced by those who live within that particular social and cultural context.
\end{abstract}

\footnotetext{
${ }^{1}$ Enviar correspondencia a: bzikic@sbb.rs
} 


\title{
perifèria
}

\author{
Número 8, Julio 2008
}

www.periferia.name

It turns that if you want to understand what does transition really mean, or how social institutions, norms, or behaviours are affected by one social system ceasing to exist, while another is not fully established yet, and what does cultural change stand for in everyday life of common people around, you must have expert and whiteness in one person, the one confident in his/her own epistemic privilege, and yet capable to join professional efforts in trying to establish the discipline able enough to serve purposes of understanding and explaining the world we are living in, being the tool of cultural critique and conceptual frame for implementing social awareness at the same time.

So in a manner of speaking anthropologist is produced somehow by the anthropology his/her professional work belongs to, where latter is shaped by social and cultural influences by the community which gives a contextual frame for whatever anthropology studies in certain social and cultural environment.

\section{I ntroduction}

This paper is about a discipline that changed its prerogatives at least couple of times in its history, about community that became familiar with wealth and progress in wrong social system, and about a scholar who is not prone to nostalgia of any kind, but is ready to explain both expectations and doubts of his surrounding that future's so bright, and we have to wear shades. I formed myself as a professional during transition, so there are no social or cultural conditions beside that I am familiar with as a trained researcher, or university teacher. I live in transitional country, and practice discipline which subject is sometimes hard to explain to general public.

I intend to present position, objects and concerns of anthropology in that particular context, but in a manner which will reveal some important stuff about that context. In order to do that, I will present the brief overview of the discipline's past, but also researches which target transitional society and its changing culture. I will present some preliminary results of my research on discourses about transition and cultural change among common people too, believing that the latter reflects some examples and controversies of one changing culture.

\section{Anthropology: the discipline and its society}

The Department of Ethnology and Anthropology, Philosophy Faculty, University of Belgrade is the only place where you can study anthropology in Serbia; it offers the 


\section{perifèria}

Número 8, Julio 2008

www.periferia.name

only curriculum devoted exclusively to anthropology and ethnology. The way the curriculum looks today is based on the change of research paradigm in Serbian anthropology. Serbian anthropology is not just Serbian ethnology upgraded, although it is true that anthropology in Serbia is rooted in ethnography and ethnology; it is more kind of agenda-hopping in part of humanities devoted to fieldwork, theoretical research, methodological advances and (self) reflexivity filed together.

In late January 1880 Act on Changes and Supplements in the Organization of Belgrade Lyceum listed Comparative Geography with Ethnography, among the other courses. Some fifteen years later, Ethnology as the autonomous course within the geographical curriculum was taught by famous Jovan Cvijić, while Ethnology Seminar was founded in 1906 (Ковачевић 2001b: 78, 76). Latter is officially recognized as a beginning of ethnology and anthropology curriculum at the University of Belgrade.

Early concept of teaching ethnology at the University of Belgrade considered ethnology as distinctive to ethnography, as the translators had been able to match the distinction between the connotations of German words Volkskunde and Völkerkunde; the truth is they usually did not. Anyway, the general idea was that there is a need of keeping and preserving Tradition and tradition was meant to be equalled with the notion of National, thus comprising both material and intangible heritage of folk. Not so original idea, of course, common to European esprit du temps from fin de siècle to WWII, but worthy mentioning here because it influenced both public and academic discourses on disciplines dedicated to studying anything associated with living people, tradition or so. The general outcome was that the ethnology was established to be considered as "science of folk and its ways" (Cf. Влаховић 1979, Ковачевић 2005, Жикић 2003-2004).

The curriculum stayed almost the same through 50 s and 60 s, until mid-seventies; it was restructured in 1973 following the idea of supporting the tendency of anthropological upgrading of discipline. That was when the name anthropology has been mentioned officially for the first time, listing Department's cathedras (Cf. Барјактаровић 1963, Павковић 1998). It was motivated primary by the need to 


\section{perifèria}

Número 8, Julio 2008

www.periferia.name

present versatility of research problems, and to demonstrate the advantages of applying western anthropological theory and methodology to them, suggesting leaving behind the socio-cultural claustrophobia, usually characteristic to science considered to be national.

Recent phenomena or modern/post-modern interpretations of those from traditional culture dominated both research and teaching ever since 1980s. Applying general researching and interpretative paradigms accepted by international anthropological community is focused on modern society and problems inherent to it (Cf. Ковачевић 2005). The attitude that "the science of everything accumulates knowledge on nothing" redirected subject orientation towards reinterpretation of "classic" phenomena in new discourses, but also opened the door to disciplinary self-reflexivity as one of its legitimate subjects, and encouraged developing some researching case-studies into curriculum courses.

Among any other filed of interest Serbian anthropology performed its researches within concerning transition and cultural change, I will stress here just few of those which portray such issues, as well the discipline, the best as I think. These are the process of privatization, matters of cultural identity, rethinking the national symbols, and investigating position of anthropology in one changing society.

Unlike other transitional milieus, countries of the former Yugoslavia have had contact with privately owned business in their pre-transitional period, i.e. in the era that preceded their economic, social and cultural transformation into capitalism. Private entrepreneurs in Serbia have always had a unique status from a legal, social, and culturally cognitive position. They have been disadvantaged in some things, mostly in matters of taxes, health insurance or so in Socialism, then they became a point of mystification during 1980s and 1990s, due to their ability to compete when market is not defined strictly, while today private ownership not just dominates industry and economics, but it is a bit out of cognitive reach that things could have looked that way ever (Žikić 2007b). 


\section{perifèria}

Número 8, Julio 2008

www.periferia.name

The process of privatization, in other words the transformation of the former state owned property, into private property, represents an element of the "transitional package" that brings about expectations of procurement for the ex-socialist societies into a state of "new economic normality" that is, in today's societies and economy, represented by liberal capitalism. In the examination and analysis of the privatization through the economic, governing and expert milieus, this process is frequently situated in the context of economic and political study. The investigation of the social and cultural implications of the process that stems from privatization, latter representing not only a modification of the ownership structure, but a complex process in which there is an encounter of the different business and organizational cultures of "East" and "West", tends to re-examine and revise some of the basic cultural categories, such as time, the idea of a person, concept of production, labour, as well as the questions of responsibility, freedom, creativity, independence. From such a perspective, that is pursued by many anthropologists who deal with post-socialist countries, it comes about that privatization will foster, not only, a novel mode of ownership and a new breed of business, but primarily, a new category of social individuals, that are expected to epitomize the new economic and social order, in which they are successfully integrated, so as to reproduce it. In other words, the "disciplining" of the manufacturers, is intrinsically linked to the transformation of the logic of economy that is based upon the "independent consumer" that twists privatization into an ambiance in which questions of responsibility, choice, freedom and coercion, are discussed and negotiated. Such queries have been inspected through a privatization of a local brewery city of Pančevo in 2003, or through a negotiation on developing tourism and services in otherwise mostly rural part of Eastern Serbia, or even by analyzing discourses on privatization and transition, and their emergence in folklore-like forms (Cf. Erdei 2007, Ердеи 2003, 2005, Баћевић 2006, Kovačević 2007a, Antonijević 2007).

Analysis of contemporary folklore demonstrates similar reception of the cultural change, and that what the different social groups are hoping will happen "at the end", or "will I get some off the social wealth redistribution too, finally?" "Inventing tradition" works not just when it is about national symbols. Sausage-festival and 


\section{perifèria}

Número 8, Julio 2008

www.periferia.name

egg-plant festival at the countryside, or at small-towns, are some examples of how new forms of functional "tradition" are created in transition, different than earlier forms of what was considered as "transition", latter being invented also, with selfreferential purpose. Those events compensate lacking of any resource in social or natural locality which eventually could be found as a tourist attraction in itself (Ковачевић 2007).

Community studies appeared in Serbian anthropology as a response to filed observations and everyday life experiences that rooting the identity may be has to do something more with locality, than with ethnicity. They are performed mostly in Vojvodina, which means in the part of the country where most of the non-Serbian population lives, and where ethnic differences are supposed to be more conflictgenerating then anywhere else. This fact somehow brought back studying the identity in communities like that from ideological production of tradition and symbolical level to actuality of what is of primary interest to the people.

So research problems were identified as modernization of institutions and everyday life in community, factors of integration of heterogeneous community and multicultural tolerance, reconstruction of "national culture" for reasons of commerce and services, overgrowing the life of so called bedroom communities at the edge of industrial cities, social and cultural issues regarding the infrastructure, etc. (Cf. Жикић 2005, Горуновић 2003, Gorunović 2007). And concerning identity, researches in multicultural communities showed that defining some real person in everyday life only by his/her ethnicity or national identity could be accepted only highly contextual, for identity is presumed as composed structure consisting of different elements of personal interests and motives (Жикић 1997, 1998).

Burden of transformation and change was not carried by economy itself. It affected ways people think of themselves, world, and everything that lies between those. Spiritual life and institutional religion have been investigated, as eventually traditional field of anthropological research, in an attempt to identify the key notes of their changing since pre-transitional times (Cf. Радуловић 2003, Синани 2006, Radulović 2007). Even some of the national symbols have been challenged as a result of the cultural change touch. Besides the public discussion on principle signs 


\section{perifèria}

Número 8, Julio 2008

www.periferia.name

of the country, like flag or anthem, the concept of national holidays also had to leave behind what was significant in Socialism, and to find what is proper for the new dawn rising. Former society favoured holidays reminiscent to events of WWII and establishment of the socialist state. Milošević's regime did not want to give away of those either, although tried to stress some dates considered important to Serbian nation too. It was kind of an urge to establish new national day after October 2000. Anthropological analysis explains why one particular holiday suited perfectly for democratic- and liberal-prone Serbia, although being a religious feast by its origin (Cf. Kovač 2007).

Sretenje, or The Presentation of Our Lord and Savior in the Temple, was introduced as Serbian national day, as it was the day The First Serbian Uprising against Ottoman rule took place in 1804 . It was also the day some 30 years after the Uprising the first Serbian Constitution has been declared, the latter being too liberal for that time, and Serbian government was forced by European powers to overrule it. It is obvious that the political, social, and cultural connotations of this holiday stretch far beyond possible notion of nationalism, making it acceptable to both "civic" and "national" parts of Serbian public opinion (Ковач 2003).

Position of anthropology in changing society has been examined also, particularly having in mind its roots in ethnology, everywhere in former Yugoslavia, wherever it was practiced. It is argued that global social circumstances, as national conflicts, push local ethnologies towards "national science", despite them being anthropologized already in certain manner prior to 1990s. Matrix to which it is stated is possible to analyse changes in politics of local ethnologies/anthropologies striving to be national is found in Double Insider Syndrome. Double Insider Syndrome refers to the interaction of three sides of the existential position of the researcher/scholar who a) is born and socialized in society he/she studies, b) accepts belonging to a distinctive community of publicly engaged intellectuals who advocate the interests of their community, and c) perceives the community he/she belongs as politically, economically, or culturally threatened, or repressed in another sense (Naumović 1998). 


\section{perifèria}

Número 8, Julio 2008

www.periferia.name

Serbian anthropology did not take the path of national science. Rethinking its position within society engaged in serious changes and economic transformation suggests paradoxical compromise between ethnographic realism and cultural critique, capable of providing a new image for the discipline in wider contexts of cultural policy and education. The core idea is to reaffirm the discipline's critical edge by de-ethnicizing its culture while re-negotiating the position and the social role of presumed "national science". The proposed model hybridizes the ethnographic realism on which identities are based with cultural critique that advertises its own vision of multicultural tolerance. This kind of design suggests anthropology in Serbia as kind of a multicultural propedeutics, hopefully capable of facilitating its knowledge, perspective, and social hopes into the public realm after post-modern, transitional, and cultural changing of latter (Миленковић 20036).

\section{Transition and Change: people and their society}

Speaking of "transition" in itself, I would have no more to add that I see it as a process of one social and economic system transforming into another, with dramatic change of inherent cultural values and norms. The prove that Serbia is still the transitional country, if anybody needs it, lays in the bare fact that country's government still controls some crucial parts of country's business life, which on the other hand are designated to be sold out already, such as telecommunications, traffic infrastructure, motorcar or arms industry, and so on. Cultural change simply is all of that which is happening with the way of life in that social surrounding, that of people, as well that of institutions. One would expect that common wish for ending eventual marginality of transitional status of society is one-way directed towards contemporary world of liberal capitalism and its seductive consumerismbased values. Well, people mostly think of pre-transitional period as of better social, cultural, and economic context for living their lives.

Transition is usually considered as saying farewell to a depressive and repressive life under the state-controlled economy, in order to enter the shiny (happy?) world of liberalism. This colloquial pattern in fact is no different than Communists' promises that their regime will bring the "bright future" for everyone, as soon as they get even with everything that had existed before they came into power. The 


\section{perifèria}

Número 8, Julio 2008

www.periferia.name

easiest way to justify some present deeds is to make promises about future, by scorning the past. It does not surprise then when Western people, including scholars and politicians, do not understand the ambiguity which exists in Serbian public when it is about not joining the EU in itself, but the goals of that adventure.

Among several points of significance regarding to this, such as quality of life, matters of ideologies, intra-social and -cultural ambiguity concerning the social and cultural priorities, and kind of cultural cognitive auto-portraying, quality of life is singled out as a point of non-contested claims that what we are about to incline to, considering how do we live, should be similar to how we used to live before all hell broke lose. It is clear today that discourse about how life was before transition is shaped as kind of a story about the golden age and I will present core parts of that discourse, those concerning culture of dwelling, education, health service, social security, employment, as well freedom to move.

My aim in doing this is to show why my fellow countrymen and -women are not eager by default to accept whatever they are asked to, by social, economic, political, educational, and cultural reformers, acting as transitional agents, from inside the country or from the international institutions concerned. They mostly think with strong criticism of transition as of social and cultural change, having in mind that many of the changes in real life should be considered as deterioration of quality of their life as it used to be at least in 1970s and 1980s, even when those changes are intended to improve quality of their life as it is now. And I am not talking of the things which undeniably makes life of today more comfortable than the one of twenty years ago or more, like Internet, cellular phones, or therapy for certain illnesses. Those should be considered as a result of general development by themselves. I am not talking of availability of those either, although this could be an interesting issue for discussing transition, considering ordinary persons' point of view. I am just about to present discourse and facts on several aspects of life people in Serbia consider important, where some of them are left behind usually in scholars' discussions on effects of transition to society and its people. 


\section{perifèria}

Número 8, Julio 2008

www.periferia.name

Owning one's own dwelling real estate is considered as conditio sine qua non in Serbia, when determining both achievements in life and its quality. It is true that most of the adults born in the settlement they actually live, do live in habitat they own. Unfortunately, this does not include certain numbers of refugees and almost none of the so called internally displaced persons It is not applicable mostly also to the people who left places of their origin and moved to some big cities for education, in searching for job, or pursuing their careers, mostly to Belgrade and Novi Sad.

The usual way of building in Serbia today is almost the same, as it was in 1970s and 1980s: the foundations are dig and the concrete table is casted; then the brick is plastered with mortar, all the way each wall of the building is positioned, from the foundation to the last floor; this construction is strengthen then with iron rods, which will serve as armature for the concrete; then the concrete is casted around each wall, including floor-boards, and the building is ready to be put under the roof, and painted, etc.

Being used to live in solid buildings, people in Serbia felt uncomfortable with big constructing companies from the West, entering market after 2000, offering new building materials, maybe cheaper, but not reliable at all, compared with brick-andmortar-based buildings. Materials like plaster, or wood, have been considered as "paupers' materials" in building the houses in Serbia since the long time ago. Plastics and other similar materials have not been paid too much attention either, since people were suspicious about their ability to sustain extremely changing weather conditions in Serbia throughout the year, to give protection against moisture and heat, and about their durability.

The banks were owned by the state in socialist Yugoslavia, and loans for buying real estates used to be favourable enough, for the most of the people who were employed. That is way renting the dwelling places never was corporate business in Serbia, and there are no buildings for dwelling entirely for renting in Serbia still. That is also why constructing the building with some comfortable flats is preferred than building the house by oneself. It is cheaper to maintain the flat considering prices of heating, electricity, running water, cable television or so, and it is easier to 


\section{perifèria}

Número 8, Julio 2008

www.periferia.name

keep it clean, dry and warm, with the need of whitewashing it only once in several years, and not annually, as it is case with the house. When contractors are ready to build, people who are mostly interested in buying the flat(s) are those who will live in it (them), immediately when building is constructed or in some near future.

Contractors secure their job financially by signing the fore-contract with eventual buyers, which is the legal step preceding the building. Buyers secure their future property on the other hand by that act; hence the both sides get what they need before construction started: contractors find the investitures among buyers, while buyers are gained rights to overlook the process of their property coming to be. This is crucial somehow to housing business in Serbia.

So what are the transitional obstacles for the comfortable culture of dwelling? First, there are no state-owned banks offering easy-to-handle loans any more. Banks of today mostly are subsidiaries of major foreign banks, seeking profits on their own, which makes almost impossible for most part of population who do not own dwelling property to afford self one. Then, adjusting the laws to EU legal norms concerning housing is disfavourable for the way business is performed until recently. People are afraid that insisting on new building materials will negatively affect the quality of buildings, while the obligatory regulations in effect now will be dismantled by being tagged as market non-competitive. The latter means loosing choice and control over the process of building for buyers, leaving them with the products they were not able to evaluate during their design.

It is claimed that there is a causal link between education and employment in developed countries. Better educated you are better job you will get. This is usual statement by social and educational reformers in Serbia. It is claimed further that transition is a process which enables country's capacities building in order to reach social and economical stability and wealth as those which are known in developed countries. What is associated to that, almost by default, is concept of health service capable of providing public services of quality and distinction for each and every member of society, no matter his/her age, social or economic status. This in turn, together with subtly elaborated social services, based on the fair re-distribution of wealth, should make a foundation for social security as some kind of a trade mark 


\section{perifèria}

Número 8, Julio 2008

www.periferia.name

for the look of society wanted to be reached.

Well, we almost have had some success in reaching society like that in former Yugoslavia, before everything gone to hell. That also included the economic ability for buying quality goods; the easiness of supporting in everyday living, by satisfying the basic needs for foods, sheltering maintenance and leisure activities; the children being safe when they are in schools, with lots of extracurricular activities provided by educational authorities (sports, drama, literary, science, mathematics, folklore etc. sections); academic achievements as the impetus for upward mobility; reliability of medicine services etc.

However, the most important feature of positive picture of former social system in people's remembrance is job security. It was the peak of cumulative legislative factors stemming out of labour, education, health, and social security legal acts. It was almost impossible for a person to lose the job once he/she got it, unless for making some serious offenses, like causing major financial or production harm for company, or hurting somebody really badly.

All of that collapsed obviously: may be education is not poor itself, but schools became more violent place in last 15 years or so, you have to pay to any decent medical service, social services almost do not exist any more, for many there barely are any job, so it is obsolete to talk either of job security at all, or of the link between education and job, many of the employers openly disobey the rules considering their obligations towards their employees, and no one could prevent them in doing so or impose any sanction upon them (should state be the one to react? It is blamed for that anyway), money and power often are in the hands of people without any education, lacking any social compassion etc. People are not interested in why the system ceased to function; they are aware that it does not operate any more, that there lives are harder than they used to be, and they remember that there were times when everything was different. 


\section{perifèria}

Número 8, Julio 2008

www.periferia.name

Transition did its turn considering women too. Women used to have the same wages as the men for the same job, and they were appointed to managerial positions often in socialist Yugoslavia. They also received full payment for the year after giving birth to the child, free from going to work for that period of time. Nowadays the battle for equalling wages for the same post concerning sex/ gender is to be won again; many women hesitate even to marry, in order not to loose their jobs, because some employers may interpret that as the first step toward having a child; they receive only $65 \%$ of their wages while on maternal leave; maternal leave is up to six months now.

One of the major achievements of Tito's regime was opening the borders in late 1950s. Yugoslavs became extremely mobile when travelling the globe since then, which included both economic migration to Western Europe and North America, as well business trips and tourism worldwide. Maybe the principle prerequisite for that used to be visa-free regime, which Yugoslavia had with most of the world (including Western Europe). As it was expected, and which is contrary to contemporary bureaucratic claims from EU, income or the way of living at home did not influence much who had travelled.

I will give you the example of "the enlightened visa regime" which is applied to Serbian citizens by EU since January 1 2008, as some kind of gesture of good willing: what I needed to get to Spain, amongst the other, was the conferment by my Faculty that I am employed there, with the exact date from where it started, with my current position and duties, the information about my salary, and about my vacancies; then I needed conferment for my bank that I am in possession of a valid bank account, with excerpts from it for at least three months, displaying all of the cash-flow, but I needed also the conferment from National Retirement Insurance Service that there exists the file with my name within its archives, where all of financial, educational, and professional facts on my career are stored. And all of that after I have been officially invited by the distinguished academic institution from Spain . 


\section{perifèria}

Número 8, Julio 2008

www.periferia.name

I would not question here any kind of discourse by EU officials on this topic, although that could make an interesting discussion, because I want to present how people in Serbia perceive things. For many people, as for me too, sincerely, the message sent by all of that is something like: "we don not believe neither you, as a person and a citizen, nor your employers, for all of you are the same scum, ready to lie in order to come to us and rob us, so any kind of intrusion in your private or professional life is just enough, for you are ready to sell your own children in order to pauperize us, and we have the God-given right to arbitrate in what is good and what is wrong, for us, as for you, or for anybody in the World, and our decisions are not to be questioned, at least not by you, for you must be happy if we show our mercy to share with you the leftovers from our table".

\section{Anthropology to the People: anthropologist of the own society}

I have already said that people mostly think of pre-transitional period as of better social, cultural, and economic context for living their lives, than of the times yet to come. It is kind of a dominant discourse of ordinary people over 25-30 years of age, which is accepted by youth, pretty much as an axiom, latter ready to believe that there is more to life for them than is feasible currently. Public discourse as shaped by media and politicians, on the other hand, tends to ignore past often, stressing the political reality of nowadays, as the principle force determining both ways and quality of social and economic institutions as they look now, and as how they ought to be once when Western standards are achieved.

There are several implications of this brief description. There is obvious distinction between two discourses in that ordinary people's one tends to be evaluative, and media's and politicians' one tends to be judgmental. The first one is clearly subjective and emotional, while the other seeks its credibility by presuming itself to be more objective and rational. Taking any of them as granted, or scrutinizing them, one has to assume that both of them make the outskirts for depicting cultural change, which has been taking place for almost couple of decades. 


\section{perifèria}

Número 8, Julio 2008

www.periferia.name

Living in Serbia nowadays is not significantly better or worse than in countries with similar social and cultural experiences indeed. But it is worse in what we had not too long ago, and what is not forgotten by ordinary people. This latter is true for the rest of former Yugoslavia, save perhaps for Slovenia, yet it is the question why people in the countries that also stemmed from it do not claim their recent social and cultural past so vigorously against the outcomes of liberal capitalism. Frankly, I do not know if they do in the same way, or they do not at all, but Serbian particularity considering transition is that the latter did not follow establishing or reestablishing the national state.

Serbia regained independence last of all other Yugoslav countries, although it had had it first, back in 19th Century. And that happened without any of Serbia's active effort, when Montenegro voted independence in 2006. Thus sense of losing among ordinary people and loser's activity of country's political establishment contributed to the attitude in general public that whatever is to be achieved today, after deterioring 1990s, is nothing more than a whiter shade of pale, compared to how it was once. No matter how it was once for real, or how it is it now really. May be it has to do something with the way politics is established as a discourse-maker in Serbia.

Majority of key figures in political life of Serbia were thinking within the framework of Serbian political idiom that was constructed throughout 19th and the first half of 20th Centuries. Base of that framework was integrationist nationalism, i.e. to create the state which will encompass all of the Serbs, wherever they may live in Balkans. That is partially the reason why federative Yugoslavia used to be so favoured among principle political players from the Serbian side, virtually to the last moments of any multinational state on territory which once was Yugoslavia.

This nationalism used to be considered as integrationist within Serbs by themselves, but it was ascribed an anti-imperial feature also, being result of bicentennial fights against different imperialisms: Ottoman, Hapsburg, German, Nazi and Fascist. It was hard for Serbian elite to accept that integrationism of its nationalism could have been perceived by imperial a bit within different communities, and that nationalisms of latter, accused by the first for separatism 


\section{perifèria}

Número 8, Julio 2008

www.periferia.name

and particularism, show no crucial differences than Serbian nationalism, including the omnipotent "just cause" for its existence. This way or another, economic globalization favoured ethno-nationalisms, regional autonomisms, and other forms of political particularism, so Serbian nationalism, together with its derivation, Yugoslav pan-nationalism, were doomed to failure (Ribić 2007a, b).

What I have presented mostly is the level of cultural cognition on these matters, of course, but as it is usually so, that is supported by some facts. It is true that in transition many of social and cultural items are relativized and destabilized, with often dramatic consequences for the lives of real people. For social science and humanities, as well for their practitioners, that means a playground of their own, if not kind of a paradise lost by itself. There is no other way even to try to understand what is happening in the society and its culture and with them, but to turn to the disciplines equipped with research, analytical, and interpretative tools for tasks like that.

With rich experience in community-based researches, with an eye for a detail when it is up to making the link between the fact and interpretation, in order to avoid faceless generalizations, and with accumulated knowledge on how different cultures and subcultures are conceived, perceived and performed within Serbian society, being those ethnic, religious, local, or based on any other principle of classifications, Serbian anthropology, growth from Serbian ethnology indeed, proved itself as particularly suitable for finding the explanations of how people, institutions, or social/cultural groups live, and is keen enough to understand contextual differences between them, no matter how tiny those might be.

Researcher's part, i.e. anthropologist's part in all of that is something in between his/her perspective as a member of society and cultural impropriator/inheritor, and perspective of a scholar. It is somehow peculiar to basic tradition of anthropology to study oneselve's way of living. Well, "exotic Others" do not live in rural parts of the world any more, there are many more proves of it in contemporary anthropology all over the world; Serbian anthropology included too. 


\section{perifèria}

Número 8, Julio 2008

www.periferia.name

When it is up to how transition affects anthropologists' perspectives on their professional work in Serbia explicitly, that it is mostly by defining subjects of the research, redirecting research interests to problems that people are faced with everyday life, the problems which somehow make all members of culture "exotic" and "Other" to what they presume their lives should look like, with references to the both sides of temporal axis, to "glorious past", and "brighter future". Looking this way, the transition could be described also as status of one society and its culture something in between what has been achieved once, and what has to be achieved one day, in order that good life could be reached for the majority of population.

The truth is however that the rise, development, and the multitude of theory, method, and objects of anthropology in Serbia is in conjuncture with the decline of its society, regarding both the efficiency of social institutions and the quality of living, compared to what has been experienced some couple of decades ago. Anthropologist him/herself stands something in between the worlds in which he/she lives and in which he/she studies how people live, being part of both of them at the same time. It is an advantage for him/her as a researcher, but sometimes more a burden for him/her as an ordinary person from a real world.

\section{References}

Antonijević, Dragana (2007). Merkantilne legende postindustrijskog društva. u Nedeljković 2007.

Антонијевић, Драгана (2007а). Карађорђе и Милош. Између историје и предања, Београд: Српски генеалошки центар и Одељење за ентологију и антропологију Филозофског факултета књ. 32.

Антонијевић, Драгана (2007b). Карађорђе и Милош. Мит и политика, Београд: Српски генеалошки центар и Одељење за ентологију и антропологију Филозофског факултета књ. 33.

Baćević, Jana (2006). Honour and Shame: prilog alternativnoj istoriji srpske etnologije. Етноантрополошки проблеми н.с. год. 1 св. 1, 95-100. 


\section{perifèria}

Número 8, Julio 2008

www.periferia.name

Барјактаровић, Мирко (1963). Катедра за етнологију. У Сто година Филозофског факултета, Београд: Филозофски факултет, 287-300.

Ердеи, Илдико (2003). Потрошња и идентитет у савременој Србији - народне представе о богатству и сромаштву, у Радојичић 2003.

Ердеи, Илдико (2005). Богатство у транзицији - концептуализација богатства на примеру два књажевачка предузетника, у Ковач 2005.

Erdei, Ildiko (2007). Dimenzije ekonomije: prilog promišljanju privatizacije kao socio-kulturne transformacije. U Ribić 2007.

Горуновић, Гордана (2003). Просторно-физичке и друштвене карактеристике панчевачког насеља Миса Виногради. у Радојичић 2003.

Gorunović, Gordana (2007). Postsocijalizam i tranzicija, lokalne zajednice i identiteti. U Nedeljković 2007.

Ковач, Сенка (2003). Поруке предлагача нових државних празника Србије. У Радојичић 2003.

Ковач, Сенка. (2005). (ур.) Проблеми културног идентитета становништва савремене Србије, Етноантрополошки проблеми, Зборник радова, Београд: Филозофски факултет.

Kovač, Senka (2007). Percepcija novog državnog praznika: primer Sretenja. U Ribić 2007.

Ковачевић, Иван (2001a). Историја српске етнологије I. Просветитељство. Београд: СГЦ, Етнолошка библиотека, књ. 1.

Ковачевић, Иван (2001b). Историја српске етнологије II. Правци и одломци. Београд: СгЦ, Етнолошка библиотека, књ. 2.

Ковачевић, Иван (2001c). Семиологија мита и ритуала III. Политика. Београд: СГЦ, Етнолошка библиотека, књ. 5.

Ковачевић, Иван (2005). Из етнологије у антропологију (Српска етнологија у последње три деценије (1975-2005). У Етнологија и антропологија: стање и 


\section{perifèria}

Número 8, Julio 2008

www.periferia.name

перспективе. 3борник Етнографског института САНУ 21, Београд, 11-19.

Ковачевић, Иван (2007). Антропологија транзиције, Београд: Етнолошка библиотека, књ. 28, Српски генеалошки центар и Одељење за етнологију и антропологију Филозофског факултета.

Миленковић, Милош (2003а). Проблем етнографски стварног. Полемика о Самои у кризи ентографског реализма. Београд: СГЦ, Етнолошка библиотека, књ. 12.

Миленковић, Милош (2003b). Антропологија као мултикултурна пропедеутика у Србији. У Радојичић 2003.

Naumović, Slobodan (1998). Romanticists or Double Insiders? An Essay on the Origins of Ideologised Discourses in Balkan Ethnology, Ethnologia Balkanica, Vol. 2, 101-120.

Nedeljković, Saša (2007). (ur.) Antropologija savremenosti, Zbornik radova, Beograd: Etnološka biblioteka knj. 23, SGC i Filozofski fakultet.

Павковић, Никола Ф (1998). Одељење за етнологију и антропологију, у Филозофски факултет 1838-1998. Београд: Филозофски факултет, 479-493

Радојичић. Драгана (2003). (ур.) Традиционално и савремено у култури Срба, ПИ ГЕИ САНУ 49, Београд.

Радуловић. Лидија (2003). „Учење вери" - конструкција родних идентитета путем популаризације православне теолошке литературе. У Радојичић 2003

Radulović. Lidija (2007). Okultizam ovde i sada. Magija, religija i pomodni kultovi u Beogradu. Beograd: Odeljenje za etnologiju i antropologiju Filozofskog fakulteta i Etnološka biblioteka SGC, knj. 3.

Ribić. Vladimir (2007). (ur.) Antropologija postsocijalizma. Zbornik radova. Beograd: Odeljenje za etnologiju i antropologiju Filozofskog fakulteta i Etnološka biblioteka SGC, knj. 34.

Ribić. Vladimir (2007a). Antropologija raspada Jugoslavije: o etničkom nacionalizmu. U Ribić 2007. 


\section{perifèria}

Número 8, Julio 2008

www.periferia.name

Ribić. Vladimir (2007b). Srpski nacionalizam na kraju XX veka. U Nedeljković 2007

Синани. Данијел. 2006. Антрополошка проучавања феномена опседнутости: друштвени аспекти и импликације. Етноантрополошки проблеми н.с. год. 1 св. 2, 59-78.

Влаховић, Петар (1979). Развој етнологије на Филозофском факултету у Београду од оснивања до Другог светског рата. Гласник Етнографског института САНУ XXVIII, 9-19

Жикић, Бојан (1997). Билингвизам у источној Бачкој, на примеру омладине, Етнички и етнокултурни контакти у панонско-карпатском простору, Београд: ПИ ГЕИ САНУ 42.

Жикић, Бојан (1998). О разлици између етничког и културног идентитета Мађара у источној Бачкој, Етнички односи Срба са другим народима и етничким заједницама, Београд: ПИ ГЕИ САНУ 44.

Жикић, Бојан (2002). Антропологија геста II. Савремено друштво. Београд: СГЦ, Етнолошка библиотека, књ. 8.

Жикић, Бојан (2003-2004). Сима Тројановић као претеча етнолошког проучавања људског тела у Србији. Гласник Етнографског музеја 68-69, 9-21.

Жикић, Бојан (2005). Конструкција идентитета у дуалној ентокултурној заједници: Селеуш. У Ковач 2005.

Жикић, Бојан (2006). Антропологија AIDS-а. Ризично понашање интравенских корисника дроге, Београд: Филозофски факултет и Српски генеалошки центар, Етнолошка библиотека књ.19.

Žikić. Bojan (2007a). Injecting Drug Users' Utilisation of Public Space in Belgrade: Places, Risk-management, and Habitual Life, Bulletin of the Institute of Ethnography LV, No. I Serbian Academy of Sciences and Arts, 2007, 103-114.

Žikić. Bojan (2007b). Ljudi (koji nisu sasvim) kao mi. Kulturna konceptualizacija pojma privatnik u Srbiji. U Ribić 2007. 